\title{
Mitochondrial DNA restriction and genomic maps of seven species of Melipona (Apidae: Meliponini)
}

\author{
Ricardo WeINLICH, Flávio de Oliveira FRANCISCO, Maria Cristina ARIAS* \\ Departamento de Biologia, Instituto de Biociências, USP, São Paulo, SP, 05508-900, Brazil
}

(Received 27 December 2002; revised 3 September 2003; accepted 19 September 2003)

\begin{abstract}
This paper reports efforts to characterize the mitochondrial genome of Meliponini. Here we describe the restriction and partial genomic map of seven Melipona species (M. bicolor, M. compressipes, M. marginata, M. melanoventer, M. quadrifasciata, M. rufiventris and M. subnitida). The maps were obtained through RFLP and PCR-RFLP using 15 restriction enzymes. The total number of sites mapped ranged from 12 to 19 , indicating a high level of genetic diversity among those species. MtDNA total size was estimated to be $18500 \mathrm{bp}$.
\end{abstract}

Melipona / stingless bee / mtDNA / rflp / restriction map

\section{INTRODUCTION}

In a recent bee systematic review, Michener (2000) divided the family Apidae in three subfamilies: Xylocopinae, Nomadinae and Apinae. The actual subfamily Apinae comprises 19 tribes including Apini, Meliponini, Bombini and Euglossini, the "corbiculate" bees. Those 4 tribes used to define the family Apidae before Michener's revision. Although Apini is the most studied tribe of the family, it presents only one genus (Apis L.) and about 11 valid species naturally distributed in the Old World (Michener, 2000). Conversely, Meliponini is the most diverse group, presenting several hundred species distributed in tropical and southern subtropical areas of the World. The total number of species is still not established mainly because of the high number of cryptic species (Michener, 2000). Some aspects of the phylogeny and classification of Meliponini were discussed by Camargo and Pedro (1992) and Michener (2000).

Most of the studies conducted on Meliponini have been based on morphology and behavior.
However, recently, studies have been published on molecular markers suitable to investigate aspects of the biology and evolution of this group of bees (Peters et al., 1998; Bezerra, 1999; Paxton et al., 1999; Francisco et al., 2001; Costa et al., 2003). In general, mitochondrial DNA (mtDNA) analyses have proved useful due to characteristics that include maternal inheritance, high level of nucleotide substitution and small molecular size (16 kb in average). Analysis of mtDNA polymorphism has been applied to solve questions concerning population dynamics, species and subspecies characterization and phylogeny. Within the bees, mtDNA analysis has been largely employed but almost exclusively to the genus Apis (Arias et al., 1990; Sheppard et al., 1991; Garnery et al., 1992; Lobo, 1995; Arias and Sheppard, 1996; Arias et al., 1996; Franck et al., 2000; Meixner et al., 2000; Smith et al., 2000).

In a previous paper we described the mtDNA characterization of five Meliponini species belonging to the genus Plebeia Schwarz (Francisco et al., 2001). The restriction maps

\footnotetext{
* Corresponding author: mcarias@ib.usp.br
} 
are now being used as a guide to precisely locate polymorphic restriction sites in population surveys and make inferences about population dynamics and phylogeography.

In this paper we report the restriction and partial genomic map of seven species of Melipona Illiger. This genus presents a neotropical distribution, and seems to be the most derivative group, suggesting a post-Gondwanan origin (Camargo and Pedro, 1992). The number of Melipona species is estimated to be around 40, geographically distributed from Mexico to Argentina (Michener, 2000). In Brazil some species are suffering population constraints due to forest devastation (Kerr, unpublished data) and probably some species are facing extinction. The genus Melipona plays a very important role as pollinators and also some species are domesticated for honey harvesting.

Knowing the potential of mtDNA markers through Apis and Plebeia examples, the characterization of mitochondrial genome of Melipona species may contribute further to conduct population surveys in an attempt to understand the intra and interspecific genetic variability, biogeography, population dynamics and also evolution of the genus.

\section{MATERIALS AND METHODS}

The species and subspecies studied in this present work were the following: Melipona bicolor (Lepeletier), M. compressipes (Fabricius), M. marginata (Lepeletier), M. melanoventer (Schwarz), M. quadrifasciata quadrifasciata (Lepeletier), M. quadrifasciata anthidioides (Lepeletier), M. rufiventris (Lepeletier), and M. subnitida (Ducke). One nest per species or subspecies was sampled. Individuals of M. bicolor, M. marginata, M. quadrifasciata quadrifasciata, $M$. quadrifasciata anthidioides, and $M$. subnitida were collected from hives maintained at the Laboratório de Abelhas do Departamento de Ecologia do IB-USP. The colony of M. subnitida was originally from the northeast region of Brazil while the others were originally from Cunha, SP. The samples of $M$. compressipes, $M$. melanoventer and $M$. rufiventris were brought in alcohol from Pará, Brazil.

\subsection{DNA extraction}

Total DNA was extracted according to the protocol TNE described by Sheppard and McPheron
(1991) and used in Restriction Fragment Length Polymorphism (RFLP) experiments. For mtDNA genomic amplification through Polymerase Chain Reaction (PCR) the DNA extractions were performed following the procedure modified by Arias and Sheppard (1996). One or two thoraces were used per extraction. This number varied depending on the bee size, e.g. for M. bicolor DNA extractions one thorax was used and for M. marginata two thoraces.

\subsection{RFLP and Southern blot analysis}

The DNA samples were screened using the following restriction enzymes: $B a m \mathrm{H} \mathrm{I}, B c l$ I, $C f o \mathrm{I}, C l a \mathrm{I}$, EcoR V, Hae III, Hpa I, Pvu II and $S c a$ I (Boehringer Mannheim Biochemica), Bgl II, EcoR I, Hind III, Pst I, $X b a \mathrm{I}$ and $X h o \mathrm{I}$ (GIBCO BRL). The digestions were performed using $10 \%$ of the total volume of TNE extractions and $5 \mathrm{U}$ of enzyme, following the manufactures instructions, and incubated overnight. For double digestions, the DNA was first digested overnight with one enzyme, precipitated, and then digested with the second enzyme.

The RFLP products were analyzed by electrophoresis in $0.8 \%$ agarose gels, stained with ethidium bromide and visualized and photographed under UV light. The DNA fragments were transferred to nylon membrane (Amersham Pharmacia) and hybridized with heterospecific probe at $56{ }^{\circ} \mathrm{C}$ overnight. The mtDNA probe was obtained from Apis mellifera through PCR amplifications (Francisco et al., 2001). The DIG DNA Labeling and Detection Kit (Roche) was used in the next steps following the manufacturer's protocol.

\subsection{Polymerase Chain Reactions (PCR)}

Amplifications of ten mtDNA regions were performed using primers and PCR conditions already published (Francisco et al., 2001). Some modifications on the annealing temperature were necessary for the pairs of primers 3, 7 and 9 (Tab. I in Francisco et al., 2001), here we used $43{ }^{\circ} \mathrm{C}, 43^{\circ} \mathrm{C}$, and $42^{\circ} \mathrm{C}$, respectively. The reactions were performed in $50 \mu \mathrm{L}$, containing $1 \mu \mathrm{L}$ of DNA, $5 \mu \mathrm{L}$ of $10 \mathrm{X}$ PCR buffer, $1.5 \mu \mathrm{L}$ of each primer $(20 \mathrm{mM}), 5 \mu \mathrm{L}$ of dNTPs (2 mM each), 2.5 U of Taq DNA polymerase (Boehringer Mannheim Biochemica) and sterile water. The PCR products were analyzed in $0.8 \%$ agarose gels, stained with ethidium bromide, visualized and photographed under UV light.

For the PCR-RFLP technique, the PCR products were digested (single digestion) with the same restriction enzymes used for the total DNA. The fragments generated were separated in $1.5 \%$ Nusieve (FMC) 3:1 agarose gels. 
Table I. Number of restriction sites generated per enzyme for each species. In parenthesis are the corresponding abbreviations used in Figure 1.

\begin{tabular}{|c|c|c|c|c|c|c|c|c|}
\hline Enzymes & M. bicolor & M. compressipes & M. marginata & M. melanoventer & M. q. anthidioides $M . q$ & q. quadrifasciata & M. rufiventris & M. subnitida \\
\hline BamH I & 0 & 0 & 0 & 0 & 0 & 0 & 0 & 0 \\
\hline$B c l \mathrm{I}(\mathrm{B})$ & 3 & 3 & 3 & 3 & 3 & 3 & 3 & 3 \\
\hline$B g l \mathrm{II}(\mathrm{G})$ & 1 & 1 & 1 & 1 & 0 & 1 & 1 & 0 \\
\hline$C f o \mathrm{I}$ & 0 & 0 & 0 & 0 & 0 & 0 & 0 & 0 \\
\hline $\mathrm{Cla} \mathrm{I}(\mathrm{C})$ & 3 & 3 & 1 & 1 & 3 & 3 & 1 & 3 \\
\hline EcoR I (E) & 2 & 2 & 3 & 1 & 3 & 3 & 1 & 2 \\
\hline $\operatorname{EcoR} \mathrm{V}(\mathrm{V})$ & 1 & 0 & 2 & 0 & 0 & 0 & 0 & 1 \\
\hline Hae III (A) & 1 & 1 & 1 & 0 & 1 & 1 & 0 & 1 \\
\hline Hind III (D) & 4 & 3 & 3 & 2 & 3 & 3 & 3 & 3 \\
\hline Hpa I & 0 & 0 & 0 & 0 & 0 & 0 & 0 & 0 \\
\hline Pst $\mathrm{I}(\mathrm{P})$ & 2 & 1 & 3 & 2 & 2 & 2 & 1 & 2 \\
\hline$P v u$ II (U) & 0 & 0 & 1 & 0 & 0 & 0 & 0 & 0 \\
\hline Sca I (S) & 0 & 0 & 0 & 0 & 1 & 1 & 0 & 1 \\
\hline Xba I (X) & 1 & 1 & 1 & 2 & 1 & 1 & 2 & 1 \\
\hline Xho I & 0 & 0 & 0 & 0 & 0 & 0 & 0 & 0 \\
\hline Total & 18 & 15 & 19 & 12 & 17 & 18 & 12 & 17 \\
\hline
\end{tabular}

\section{RESULTS AND DISCUSSION}

A total of 27 restriction sites were generated by 11 restriction enzymes among the 7 Melipona species studied (Tab. I). The enzymes BamH I, Cfo I, Hpa I, and Xho I did not cut the mtDNA of any species. The total number of restriction sites per species varied, being the lowest verified in $M$. rufiventris and $M$. melanoventer (12 sites) and the highest in $M$. marginata (19 sites).

The Southern blot data enabled us to determine fragment length by comparison with molecular weight markers and, consequently the mtDNA total size could be estimated. The entire molecule size is approximately $18500 \mathrm{bp}$, and differences among the species were not verified by the methodology applied. The same mitochondrial genome size had been previously reported for Plebeia species (Francisco et al., 2001). In comparison to A. mellifera, Melipona and Plebeia mtDNA are about 2200 bp longer. However, some mitochondrial regions amplified through PCR presented smaller sizes than expected comparing to the corresponding regions in A. mellifera. The total difference for these defined regions was a decrease of around $300 \mathrm{bp}$ compared to Apis, although the total genome is still $2200 \mathrm{bp}$ larger. The same fact, and for the same PCR amplified regions, was reported for Plebeia mtDNA (Francisco et al., 2001). These present data corroborate our previous hypothesis that absence of intergenic regions (especially the major one located between the genes COI and COII), tRNA transpositions, and large insertions in the $\mathrm{A}+\mathrm{T}$ rich region are responsible for the mtDNA size differences verified between the tribes Meliponini and Apini (Silvestre et al., 2001; Silvestre et al., 2002). Those events (insertions, deletions, and translocations) have been described in the literature as responsible for genome size differences even among species of the same genus (Fauron and Wolstenholme, 1976; Rawlings et al., 2001).

Restriction maps (Fig. 1) were built for each species based on data from Southern blot and PCR-RFLP. The analysis of the aforementioned maps revealed seven conserved sites among the species and eight sites species specific by their presence or absence. Five out of these eight sites are related to $M$. marginata. 


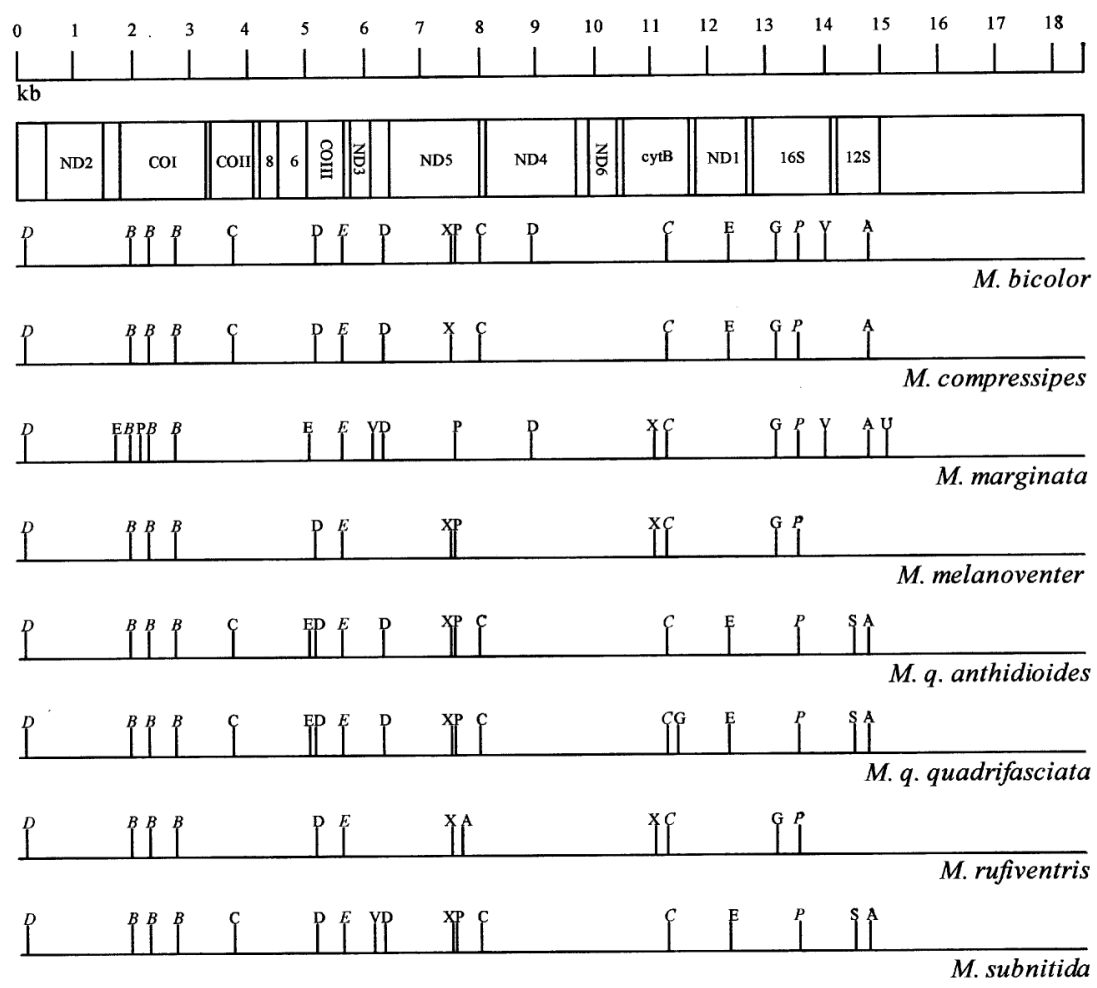

Figure 1. Linear mtDNA restriction site maps and relative main gene positions for Melipona species, using Apis mellifera mitochondrial DNA gene order as a guide (Crozier and Crozier, 1993). The italicized letters refer to conserved sites. B, Bcl I; G, Bgl II; C, Cla I; E, EcoR I; V, EcoR V; A, Hae III; D, Hind III; P, Pst I; S, Sca I; X, Xba I. ND2, NADH dehydrogenase subunit 2; COI, cytochrome c oxidase subunit 1; COII, cytochrome $\mathrm{c}$ oxidase subunit $2 ; 8$, ATP $\mathrm{F}_{0}$ synthase subunit $8 ; 6$, ATP $\mathrm{F}_{0}$ synthase subunit 6 ; COIII, cytochrome c oxidase subunit 3; ND3, NADH dehydrogenase subunit 3; ND5, NADH dehydrogenase subunit 5; ND4, NADH dehydrogenase subunit 4; ND6, NADH dehydrogenase subunit 6; cytB, cytochrome B; ND1, NADH dehydrogenase subunit $1 ; 16 \mathrm{~S}$, large subunit ribosomal RNA; 12S, small subunit ribosomal RNA.

However, it would be premature to consider these restriction sites as species specific, because population surveys for each species have not be done to evaluate intraspecific polymorphism. One example of this problem was detected in this study, the $B g l$ II site was polymorphic between the two samples of M. quadrifasciata, each corresponding to different recognized subspecies (Tab. I and Fig. 1). Thus, population surveys will be necessary to evaluate the restrictions sites as potential markers for subspecies and species characterization.

The PCR-RFLP technique used here in an attempt to better localize restriction sites close to each other, also provided information about the mitochondrial gene order. By considering the gene contents of each amplified fragments (through analogy to A. mellifera mitochondrial genome) and the position of restriction sites on the map, the main mitochondrial genes could be positioned (Fig. 1). The same methodology was applied by Francisco et al. (2001) to determine the partial genomic map of Plebeia species. Comparing the genomic maps of Plebeia, Melipona and A. mellifera we conclude that the main mitochondrial genes present conserved position.

The gene positions added to the restriction maps permitted us to visualize that five of the seven conserved restriction sites (Fig. 1) are 
located in genes that are known to be well conserved in their nucleotide sequence among animals (Simon et al., 1994): COI - three sites; cytB - one site; and 16S - one site. These five restriction sites were previously mapped at the same genomic position in Plebeia (Francisco et al., 2001) and A. mellifera (Crozier and Crozier, 1993). The two remaining conserved sites are also presented in four Plebeia species, except in P. remota (Francisco et al., 2001).

The study of Meliponini in a multidisciplinary sense is in the beginning, more data combining ecological, behavioral, and molecular characters are need to understand the biology, phylogeography, evolution and phylogeny of this important group of bees. This present paper is a contribution toward this goal. The restriction maps reported are already being used as a guide in population surveys of some species and also permitted us to infer differences in mtDNA gene order. Those inferred differences are now being investigated by sequencing and some tRNA gene transpositions have already been verified (Silvestre et al., 2002).

\section{ACKNOWLEDGMENTS}

We thank Daniela Silvestre for helpful comments and discussion; Susy Coelho for technical support; Dr Vera Lúcia Imperatriz-Fonseca and the Laboratório de Abelhas (Departamento de Ecologia do IB-USP) for providing us the biological material; Dr Lyria Mori and Dr Eliana Dessen for the laboratory facilities in the beginning. This work was financially supported by FAPESP and CNPq. $\mathrm{RW}$ was supported by scholarship from CNPq.

Résumé - Cartes génomiques et de restriction de l'ADNmt de sept espèces de Melipona. La tribu des Meliponini est le groupe le plus divers des abeilles corbiculées, mais il existe peu d'études au niveau moléculaire les concernant. L'un des genres majeurs du groupe, Melipona Illiger, comprend environ 40 espèces. Elles se répartissent du Mexique à l'Argentine et jouent des rôles écologique et économique importants. L'analyse des polymorphismes du génome mitochondrial a été largement appliquée aux études de population ou d'évolution des abeilles et des autres organismes. Dans cette étude nous avons caractérisé l'ADNmt de sept espèces de Melipona: M. bicolor, $M$. compressipes, $M$. marginata, M. melanoventer, M. quadrifasciata ( $M$. q. quadrifasciata et M. q. anthidioides), M. rufiventris et $M$. subnitida. L'ADNmt de ces espèces a été analysé avec 15 enzymes de restriction qui ont généré au total 27 sites de restriction. Le nombre total de sites de restriction a varié selon les espèces : il était le plus faible (12 sites) chez M. rufiventris et M. melanoventer et le plus élevé ( 19 sites) chez $M$. marginata (Tab. I). La taille entière de la molécule a été estimée à environ 18500 paires de bases. Des cartes de restriction ont été construites pour chaque espèce (Fig. 1) et leur analyse a montré la présence de sept sites conservés au sein des espèces. On déduit de la comparaison des cartes génomiques de Plebeia, Melipona et Apis mellifera que les principaux gènes mitochondriaux présentent une position conservée.

\section{Melipona / abeille sans aiguillon / ADNmt / carte de restriction / RFLP}

Zusammenfassung - Mitochondriale DNA Restriction und Genom Karten von sieben Melipona Arten (Apidae: Meliponini). Der Tribus Meliponini ist die unterschiedlichste Gruppe innerhalb der corbiculaten Bienen. Trotzdem gibt es von ihnen bisher kaum Untersuchungen auf molekularer Ebene. Eine der Hauptgattungen dieses Stammes, Melipona Illiger, besteht aus etwa 40 Arten. Ihre geographische Verbreitung reicht von Mexiko bis Argentinien und sie haben eine wichtige ökologische und ökonomische Bedeutung. Analysen der mitochondrialen Genompolymorphismen wurden allgemein für Studien zur Population und Evolution von Bienen und anderen Organismen angewendet. In dieser Untersuchung charakterisierten wir die mtDNA von 7 Melipona Arten: M. bicolor, M. compressipes, M. marginata, M. melanoventer, M. quadrifasciata (M. q. quadrifasciata und M.q. anthidioides), $M$. rufiventris und $M$. subnitida. Die mtDNA dieser Arten wurde mit 15 Restriktionsenzymen analysiert. Insgesamt wurden 27 Restriktions-Schnittstellen erzeugt. Die Gesamtzahl der Restriktions-Schnittstellen variierte zwischen den Arten, die niedrigste wurde bei $M$. rufiventris und $M$. melanoventer (12 Schnittstellen) gefunden, und die höchste bei M. marginata (19 Schnittstellen) (Tab. I). Die Größe des Gesamtmoleküls wurde auf annähernd $18500 \mathrm{bp}$ geschätzt. Restriktionskartierungen (Abb. 1) wurden für jede Art erstellt und die Analyse dieser Kartierungen ergab 7 konservierte Regionen innerhalb der Arten. Aus einem Vergleich der Genomkarten von Plebeia, Melipona und Apis mellifera schließen wir, dass die hauptsächlichen mitochondrialen Gene konservierte Positionen darstellen.

\section{Melipona / Stachellose Bienen / mtDNA / RFLP / Restriktionskartierung}

\section{REFERENCES}

Arias M.C., Sheppard W.S. (1996) Molecular phylogenetics of honey bee subspecies (Apis mellifera L.) inferred from mitochondrial DNA sequences, Mol. Phylogenet. Evol. 5, 557-566. 
Arias M.C., Soares A.E.E., Nóbrega F.G. (1990) Improvements to the mitochondrial restriction maps for italian and africanized honey bees, Rev. Brasil. Genet. 13, 501-507.

Arias M.C., Tingek S., Kelitu A., Sheppard W.S. (1996) Apis nuluensis and its genetic relationship with sympatric species inferred from DNA sequences, Apidologie 27, 415-422.

Bezerra J.M. (1999) Caracterização morfogenética de populações de Melipona compressipes fasciculata Smith (Hymenoptera, Apidae), em diferentes ecossistemas do Estado do Maranhão (Brasil), Doctoral thesis, Faculdade de Medicina de Ribeirão Preto, Universidade de São Paulo, Ribeirão Preto, SP.

Camargo J.M.F., Pedro S.R.M. (1992) Systematics, phylogeny and biogeography of the Meliponinae (Hymenoptera, Apidae): a mini review, Apidologie 23, 1-32.

Costa M.A., Del Lama M.A., Melo G.A.R., Sheppard W.S. (2003) Molecular phylogeny of the stingless bees (Apidae, Apinae, Meliponini) inferred from mitochondrial 16S rDNA sequences, Apidologie 34, 73-84.

Crozier R.H., Crozier, Y.C. (1993) The mitochondrial genome of the honeybee Apis mellifera: complete sequence and genome organization, Genetics 133, 97-117.

Fauron C.M.R., Wolstenholme D.R. (1976) Structural heterogeneity of mitochondrial DNA molecules within the genus Drosophila, Proc. Natl. Acad. Sci. (USA) 73, 3623-3627.

Francisco F.O., Silvestre D., Arias M.C. (2001) Mitochondrial DNA characterization of five species of Plebeia (Apidae: Meliponini): RFLP and restriction maps, Apidologie 32, 323-332.

Franck P., Garnery L., Celebrano G., Solignac M., Cornuet J.-M. (2000) Hybrid origins of honeybees from Italy (Apis mellifera ligustica) and Sicily (A. m. sicula), Mol. Ecol. 9, 907-921.

Garnery L., Cornuet J.M., Solignac M. (1992) Evolutionary history of the honey bee Apis mellifera inferred from mitochondrial DNA analysis, Mol. Ecol. 1, 145-154.

Lobo J.A. (1995) Morphometric, isozymic and mitochondrial variability of Africanized honeybees in Costa Rica, Heredity 75, 133-141.
Meixner M.D., Arias M.C., Sheppard W.S. (2000) Mitochondrial DNA polymorphisms in honey bee subspecies from Kenya, Apidologie 31, 181-190.

Michener C.D. (2000) The Bees of the World, The Johns Hopkins University Press, Baltimore, MD, USA.

Paxton R.J., Weißschuh N., Engels W., Hartfelder K., Quezada-Euán J.J.G. (1999) Not only single mating in stingless bees. Naturwissenschaften 86 , 143-146.

Peters J.M., Queller D.C., Imperatriz-Fonseca V.L., Strassmann J.E. (1998) Microsatellites loci for stingless bees, Mol. Ecol. 7, 784-787.

Rawlings T.A., Collins T.M., Bieler R. (2001) A major mitochondrial gene rearrangement among closely related species, Mol. Biol. Evol. 18, 1604-1609.

Sheppard W.S., McPheron B.A. (1991) Ribosomal DNA diversity in Apidae, in: Smith D.R. (Ed.), Diversity in the Genus Apis, Westview Press, Oxford, pp. 89-102.

Sheppard W.S., Rinderer T.E., Mazzoli J., Stelzer J.A., Shimanuki H. (1991) Gene flow between African- and European-derived honey bee populations in Argentina, Nature 349, 782-784.

Silvestre D., Francisco F.O., Arias M.C. (2001) "Primeiras evidências de diferenças na ordem dos genes mitocondriais entre tribos de abelhas". $47^{\circ}$ Congr. Nac. de Genética, realizado em Águas de Lindóia, SP, Brasil.

Silvestre D., Francisco F.O., Weinlich R., Arias M.C. (2002) A scientific note on mtDNA gene order rearrangements among highly eusocial bees, Apidologie 33, 355-356.

Simon C., Frati F., Becknbach A., Crespi B., Liu H., Flook P. (1994) Evolution, weighting, and phylogenetic utility of mitochondrial gene sequences and a compilation of conserved polymerase chain reaction primers, Ann. Entomol. Soc. Am. 87, 651-701.

Smith D.R., Villafuerte L., Otis G., Palmer M.R. (2000) Biogeography of Apis cerana F. and A. nigrocincta Smith: insights from mtDNA studies, Apidologie 31, 265-279. 